\title{
THE MARSH FROGS (PELOPHYLAX RIDIBUNDUS COMPLEX) IN CENTRAL KAZAKHSTAN: EXPANSION AND RETREAT
}

\author{
T. N. Dujsebayeva', A. Yu. Ivanov' ${ }^{2}$ A. G. Kaptyonkina ${ }^{3}$, D. A. Ualiyeva ${ }^{4}$, \\ V. N. Krainyuk ${ }^{5}$, A. V. Cherednichenko ${ }^{6}$, V. A. Khromov ${ }^{7}$ \\ 1, 3, 4 Institute of Zoology MES RK, 93 al-Farabi avenue, Almaty, 050060, Kazakhstan \\ ${ }^{2}$ Penza State University, 40 Krasnaya street, Penza, 440026, Russia \\ ${ }^{5}$ LLP Research and Production Center for Fisheries FC MEGNR RK, 43 Kenesary street, Nur-Sultan, 010000, Kazakhstan \\ ${ }^{6}$ Turan University, 16A Satpayeva street, Almaty, 050013, Kazakhstan \\ ${ }^{7}$ Shakarim State University, 20A Glinki street, Semipalatinsk, 071412, Kazakhstan \\ 1dujsebayeva@mail.ru,2akella58@mail.ru,3alyonakaptyonkina@gmail.com, \\ ${ }^{4}$ daniya.2010@mail.ru, ${ }^{5}$ karagan-da@mail.ru, ${ }^{6}$ geliograf@mail.ru, \\ 7 khromov-victor1955@yandex.kz
}

Abstract. For two decades after an occasional introduction in the middle of the 2oth century, marsh frogs (complex Pelophylax ridibundus) have spread across many water bodies of Central Kazakhstan (Kazakh Upland, KU). The questions of which genetic forms of the complex have become entrenched in the region and how successful the progress of their present settlement has been were priorities for our study. The survey of the region was carried out in May-August 2021, covering the seasons of mating and early growth. Molecular genetic analysis was performed for the mitochondrial ND2 gene. In contrast to what had been expected, our study showed a reduction in the area inhabited by marsh frogs in $\mathrm{KU}$, and a noticeable decrease in their abundance. The frogs disappeared from many points in the Nura and Ishim rivers, and significantly decreased in number on the western and northern coasts of Lake Balkhash. However, it remained a common species in the floodplain of the Irtysh Rivers and on its tributaries. For the first time for the KU the genetic affiliation of the populations (by mitochondrial ND2 gene) was determined and the habitation of two genetic forms - the invasive Anatolian P. cf. bedriagae and the native "Balkhash" form. The habitat of $P$. cf. bedriagae was established as being on the northern coast of Lake Balkhash. The native "Balkhash" form was identified on the western coast of Lake Balkhash and in the River Shar (Irtysh River Basin). In the rest of the $\mathrm{KU}$, the distribution of the two forms was variegated, and in a number of water bodies they lived together. To the north of KU lives Anatolian P. cf. bedriagae (in Kostanay and Pavlodar provinces); and to the south the "Balkhash" form (in the Balkhash-lli Depression, Almaty City and Lake Issyk-Kul). The relationship between a change in climatic cycles and the success of the past dispersal of amphibians and the present reduction in their populations in the region has been marked. The disappearance of the frogs on Lake Balkhash is most likely due to the dispersal of the snakehead (Channa argus). Molecular genetic analysis data indicated a wider distribution and wider adaptive potential of $P$. cf. bedriagae than previously thought. The study identified a number of promising tasks for future.

Keywords: Pelophylax ridibundus complex, dynamics of distribution, genetic diversity, mt-ND2 - gene, Kazakh Upland

Financing. The work is supported by a grant project from the Ministry of Education and Science of the Republic of Kazakhstan "Genetic polymorphism and ecological plasticity as the basis of evolutionary welfare and progressive settlement of the marsh frogs of the Pelophylax ridibundus complex in Kazakhstan" for 2020-2022 (No. AP08856275).

Acknowledgments. The authors are grateful to S. A. Pachin (Almaty), E. V. Arkhipov, S. Baltasheva and Yu. Bossert (Burabay), N. E. Tarasovskaya and S. V. Titov (Pavlodar) and S. V. Starikov (Ust-Kamenogorsk) for their assistance in the fieldworks and help in the collection of the material; to D.V. Malakhov for technical assistance in preparing of the maps of distribution of the marsh frog; to R. Sim (http://www.expertenglish.com) and G. Dyke for English correction.

For citation: Dujsebayeva T.N., Ivanov A.Yu., Kaptyonkina A.G., Ualiyeva D.A., Krainyuk V.N., Cherednichenko A.V., Khromov V.A. The marsh frogs (Pelophylax ridibundus complex) in Central Kazakhstan: expansion and retreat. Russian Journal of Ecosystem Ecology. 2021;6(3). Available from: https://doi.org/10.21685/2500-0578-2021-3-3 


\title{
ОЗЕРНЫЕ ЛЯГУШКИ (КОМПЛЕКС РELOPHYLAX RIDIBUNDUS) В ЦЕНТРАЛЬНОМ КАЗАХСТАНЕ: ЭКСПАНСИЯ И ОТСТУПЛЕНИЕ
}

\section{Т. Н. Ауйсебаева', А. Ю. Иванов ${ }^{2}$, А. Г. Каптенкина , А. А. Уалиева 4 , В. Н. Крайнюк ${ }^{5}$ А. В. Чередниченко ${ }^{6}$, В. А. Хромов ${ }^{7}$}

\author{
1, 3, 4 Институт зоологии Республики Казахстан, Казахстан, 05006о, г. Алматы, пр. аль-Фараби, 93 \\ ${ }^{2}$ Пензенский государственный университет, Россия, 440026, г. Пенза, ул. Красная, 40 \\ ${ }^{5}$ Северный филиал Научно-производственного центра рыбного хозяйства, Казахстан, 0100о0, г. Нур-Султан, ул. Кенесары, 43 \\ ${ }^{6}$ Университет «Туран», Казахстан, 050013, г. Алматы, ул. Сатпаева, 16А \\ ${ }^{7}$ Семипалатинский государственный университет имени Шакарима, Казахстан, 071412, г. Семей, ул. Глинки, 20А
}

1dujsebayeva@mail.ru, ${ }^{2}$ akella58@mail.ru, ${ }^{3}$ alyonakaptyonkina@gmail.com,

${ }^{4}$ daniya.2010@mail.ru, ${ }^{5}$ karagan-da@mail.ru, ${ }^{6}$ geliograf@mail.ru,

7 khromov-victor1955@yandex.kz

Аннотация. За два десятилетия после непреднамеренной интродукции в середине прошлого века озерные лягушки (комплекс Pelophylax ridibundus) освоили многие водоемы Центрального Казахстана (Казахский мелкосопочник, КМ), хотя природные условия территории мало тому способствовали. Вопросы о том, какие генетические формы комплекса укрепились в регионе и насколько успешен прогресс их настоящего расселения, были приоритетом нашего исследования. Обследование региона проводилось в мае-августе 2021 г., охватывая сезоны размножения и подроста молодняка. Молекулярно-генетический анализ проводили по митохондриальному гену ND2. Вопреки ожидаемому наше исследование показало сокращение территории, населенной озерными лягушками в КМ, и заметное снижение их обилия. Лягушка исчезла из многих пунктов долин рек Нура и Ишим, заметно сократилась в числе на западном и северном берегах озера Балхаш. Однако она осталась обычным видом в пойме р. Иртыш и на ее притоках. Впервые для региона была определена генетическая принадлежность популяций и установлено обитание двух генетических форм - инвазивной анатолийской P. cf. bedriagae и нативной «балхашской» формы. Обитание P. cf. bedriagae установлено для северного берега озера Балхаш. Нативная «балхашская» форма идентифицирована на западном берегу Балхаша и в бассейне р. Шар - левом притоке Иртыша. На остальной территории КМ распределение двух форм имеет пестрый характер, и в ряде водоемов они обитают вместе. К северу от КМ живет анатолийская P. cf. bedriagae (Кустанайская и Павлодарская области); к югу - «балхашская» форма (Балхаш-Илийская впадина, г. Алматы и озеро Иссык-Куль). Отмечена связь успеха расселения амфибий в прошлом и настоящего сокращения их популяций со сменой климатических циклов в регионе. Исчезновение лягушек на озере Балхаш, вероятнее всего, обусловлено расселением змееголова (Channa argus). Данные молекулярно-генетического анализа указали на более широкое распространение и более широкий адаптивный потенциал P. cf. bedriagae, чем представлялось ранее. Исследование определило ряд перспективных задач на будущее.

Ключевые слова: комплекс Pelophylax ridibundus, динамика расселения, генетическое разнообразие, митохондриальный ген ND2, Казахский мелкосопочник

Финансирование. Финансирование работы осуществляется в рамках грантового проекта МОН РК «Генетический полиморфизм и экологическая пластичность как основа эволюционного благосостояния и прогрессивного расселения озерных лягушек комплекса РеІоphylax ridibundus в Казахстане» на 2020-2022 гг. (№ АР08856275).

Благодарности. Авторы благодарны С. А. Пачину (Алматы), Е. В. Архипову, С. Ж. Балташевой и Ю. Боссерт (Бурабай), Н. Е. Тарасовской и С. В. Титову (Павлодар), С. В. Старикову (Усть-Каменогорск) за участие в проведении полевых исследований и помощь в сборе материала; Д. В. Малахову за техническую помощь в подготовке карт распространения озерных лягушек; R. Sim (http://www.expertenglish.com) и G. Dyke за корректуру английского текста.

Аля цитирования: Дуйсебаева Т. Н., Иванов А. Ю., Каптенкина А. Г., Уалиева А. А., Крайнюк В. Н., Чередниченко А. В., Хромов В. А. Озерные лягушки (комплекс Pelophylax ridibundus) в Центральном Казахстане: экспансия и отступление // Russian Journal of Ecosystem Ecology. 2021. Vol. 6 (3). https://doi.org/10.21685/25000578-2021-3-3 


\section{Introduction}

The marsh frogs of the Pelophylax ridibundus complex represent the amphibian fauna of the Western Palearctic. In the past, they were considered as a single species Rana ridibunda Pallas, 1771 with the original distribution area in Europe; the European part of Russia; western and southern Kazakhstan, along with valleys of the large rivers of the Central Asia; and north Africa [1]. The taxonomic composition of the complex has not been definitively established, but many forms are characterized by high ecological plasticity and a pronounced capacity for expansion. Accidental introduction of Balkan P. kurtmulleri and Anatolian $P$. cf. bedriagae in the countries of central and western Europe led to the rapid colonisation of new territories by frogs, which posed a serious threat to indigenous amphibian species and not only to them [2].

A similar story is to be found in the dispersal of the northern form of $P$. ridibundus, which adapted to the Ural and Siberian climates and took root in Kamchatka, albeit in thermal waters [3-6]. Kazakhstan was no exception. Until the middle of the last century, the range of marsh frogs was limited to the western and southern regions of the country, with doubts about its actual presence in the southeast $[7,8]$. During the second half of the 20th century, the area almost doubled, and the central regions of Kazakhstan (the territory of the Kazakh Upland) became one of the most striking examples of the expansion of these amphibians. Here, in the center of the Eurasian continent, in conditions of a sharply continental climate, a poorly developed hydrographic network and noticeable salinity in standing waters, marsh frogs were absent until the last century. They appeared in Karaganda City and its environs in the late 50s and early 60s [9] and very quickly (over two decades) became widely settled along the Nura River, its tributaries, ponds and the man-made Irtysh-Karaganda Channel [8].

Marsh frogs were first noted in the bays of the western shore of Lake Balkhash in 1951 by M. N. Korelov [10], suggesting its appearance there in 1909-1939 during a period of flooding in the area. By the end of the 2000s, the frog had also settled along the freshwater part of the northern shore of Balkhash and appeared in a man-made pond and in small rivers near Bektau-Ata Mount, $70 \mathrm{~km}$ to the north of Balkhash [11]. The reasons for such a successful colonisation of new areas by the amphibians are not fully understood; but the role of climate and human activity has been discussed $[1,12]$.

Several cryptic forms of marsh frogs have recently been isolated using molecular genetic meth- ods, possibly representing separate species [13-15]. According to Akin [16], there are two forms within Kazakhstan with a taxonomic status which is unclear: Anatolian P. cf. bedriagae (located in Aktubinsk, Atyrau (former Guryev), and Uralsk); and, in all likelihood, an undescribed species, conventionally named "Central Asia 2" (Almaty).

More than fifteen years have passed since the distribution of marsh frogs in Kazakhstan was first monitored. Against the background of the amphibians spreading further across the European part of the continent and their progressive settlement in the Asian expanses, the current situation in Central Kazakhstan is of obvious interest. Bearing in mind (1) the complete lack of data on the genetic affiliation of populations; (2) current climate change on the regional scale; and (3) the increasing economic activity of humans, we set ourselves the goal of conducting a revision survey of the area of the Kazakh Upland in order to assess the current situation as regards the distribution of marsh frogs in the region, accompanying our research with genetic screening.

\section{Materials and methods}

Study area. The Kazakh Uplands (KU) is a vast flat-upland area located in the center of Eurasia. According to Gvozdetsky and Mikhailov [17], KU and Central Kazakhstan are equivalent concepts and therefore in modern sources the name "Central Kazakhstan Upland" is sometimes used [18]. KU is bounded to the north by the West Siberian Lowland; to the south by Lake Balkhash; in the west by the Turan Plain; and in the east it is adjacent to the Altai and Tarbagatai mountain ranges. Its length from west to east is $1200 \mathrm{~km}$ and from north to south 400-900 km. Its area is about 700 thousand $\mathrm{km}^{2}$. The territory is subdivided into three main types of relief. These are low mountains, upland and plains. It includes the Central Kazakhstan Main Watershed Upland (or insular lowlands and upland of the Balkhash-Irtysh Watershed); the Kokchetauskaya and Ulytau low-mountainous hills and the Chu-Ili Lowland in its most northern part as well as denudation plains with areas of shallow hills and hollows along the periphery of the region [18-20]. The maximum heights of the main mountain ranges (the Kyzylrai, Karkaralinsk Mountains and Kent) are 1360-1560 m asl.

The climate of KU is temperate, sharply continental, and arid [21, 22]. The average January temperature is $14-17{ }^{\circ} \mathrm{C}$ below zero and that of July $19-22{ }^{\circ} \mathrm{C}$ (higher in the Chu-Ili Lowland). Minimum temperatures reach $40{ }^{\circ} \mathrm{C}$ below zero, 
while summer temperatures rise to $35^{\circ} \mathrm{C}$. The average annual precipitation is $200-300 \mathrm{~mm}$ (up to $370 \mathrm{~mm}$ in the northern mountain ranges); the snow cover is thin; and droughts are frequent in summer [23].

The location in the center of the continent and the peculiarities of the climate determine the low water content of the river network and the low level of desalination of the lakes. Only the River Ishim (Irtysh River Basin) is characterized by constant inflow: the other large rivers - the Nura, Sarysu, Silyty, Shiderty, and Tokyrau - are fullflowing in spring, while in summer the water level in them decreases noticeably or they dry up partially or completely. It is normal for the larger rivers to freeze up while the smaller ones freeze completely to the river bed. In KU there are few lakes and these tend to be predominantly slow-flowing and enclosed. The two major ones are Lake Kurgaldzhino and Lake Teniz. Along with bodies of water which are fresh and brackish, there are bodies of water which are salt, with a mineralization level of $10-44 \mathrm{~g} / \mathrm{l}$. In Lake Teniz this is 81$127 \mathrm{~g} / \mathrm{l}$. Groundwater occurs at a depth of 5-15 to 30-50 m [24, 25].

The northern part of the KU belongs to the steppe zone with forb-fescue-feather grass vegetation on southern partially plowed black soils; and in the centre there is a dry steppe zone with fescuefeather grass vegetation on dark chestnut (also partly plowed) and chestnut soils. The south and east mostly represent semi-desert landscapes: here are combined steppe (sod-grass) and desert (wormwood and saltwort) plant communities under the dominance of light chestnut soils. A small area to the southeast of Balkhash lies in a desert zone $[26,27]$. The dominance of dry steppes in KU landscapes, and in the southern part of semideserts, is well captured in the name of the area: Saryarka, which is Kazakh for "yellow ridge".

Object of the research - the marsh frogs of Pelophylax ridibundus complex.

Field data collection. The area of the KU was investigated in 2021 during the summer time: from 4 to 14 May, 15 June to 20 July and 19 to $30 \mathrm{Au}-$ gust, covering the seasons of mating and early growth. Within the Central Kazakhstan main watershed upland, the Nura River Basin was examined (the main channel, tributaries, lakes and ponds, both freshwater and of varying degrees of salinity); the northern Balkhash Region (a section of the freshwater half of the lake); and the basin of the River Ayaguz on the eastern periphery of the KU. The route surveys also covered the reservoirs of the Kokchetau Upland and the adjacent plains; the western shore of Lake Balkhash within the Chu-Ili Lowlands; the left tributaries of the River Irtysh to the southward of Semipalatinsk and in the vicinity of Ust-Kamenogorsk.

Water reservoirs were visited where encounters of marsh frogs had been mentioned in previous studies; and after that the new areas were examined. The frogs and their larvae were recorded in the daytime and/or at night with obligatory GPS fixes of the location points. Along the way, we described the features of biotopes and collected material for molecular analysis. The counts of adult and juvenile frogs were carried out on standard transects of $100 \mathrm{~m}$ along the coast with a strip of $1 \mathrm{~m}$; and tadpoles were counted over an area of $1 \mathrm{~m}^{2}$. To construct the maps (Fig. 1,A,B), the coordinates of marsh frog records known before 2005 were taken from Dujsebaeva et al. [8]. The records for 2006-2020 were borrowed from the unpublished database of the first author. To show the amount of 2021 work and the percentage of frog encounters, we placed on the map the points where the frogs were present and absent. The points with frogs are marked in bold (APPENDIX I).

Molecular genetic analysis. The finger phalanges from the frogs examined (APPENDIX II) were fixed in $96 \%$ ethanol further processed in the lab via genomic DNA extraction using a standard salt protocol [28]. The ND2 gene sequence (1038 bp) was amplified with use of the universal primer ND2L1 5'-AAG CTT TTG GGC CCA TAC CCC-3' [29] and a developed specific primer ND2H1 5'GCA AGT CCT ACA GAA ACT GAA G-3' PCR products were purified for sequencing by electrophoresis in 6\% PAAG. Sequencing was performed using an ABI 3500 automatic sequencer (Applied Biosystems), using BigDye Terminator 3.1 kits (Applied Biosystems), and the same set of primers used for the PCR. When comparing the ND2 sequences of $P$. cf. bedriagae and "Balkhash" form (named as "Central Asia 2" sensu Akin, 2015) marker nucleotide substitutions were found that affect the recognition sites of the restriction endonuclease BsuRI (HaeIII) GG 'CC.

PCR fragments were hydrolyzed for $2-4 \mathrm{~h}$ at $37{ }^{\circ} \mathrm{C}$ by adding $2-4$ units of enzyme activity directly to aliquots of amplification mixtures $(4 \mu \mathrm{L})$. The results of the restriction analysis are shown in the Fig. 2. When treated with endonuclease, the $1170 \mathrm{bp}$ fragment to be amplified in the analyzed forms is cleaved into 5-7 fragments of various lengths, which form specific restriction patterns. This makes it possible to diagnose how the specimens relate to the analyzed mitochondrial lines. 

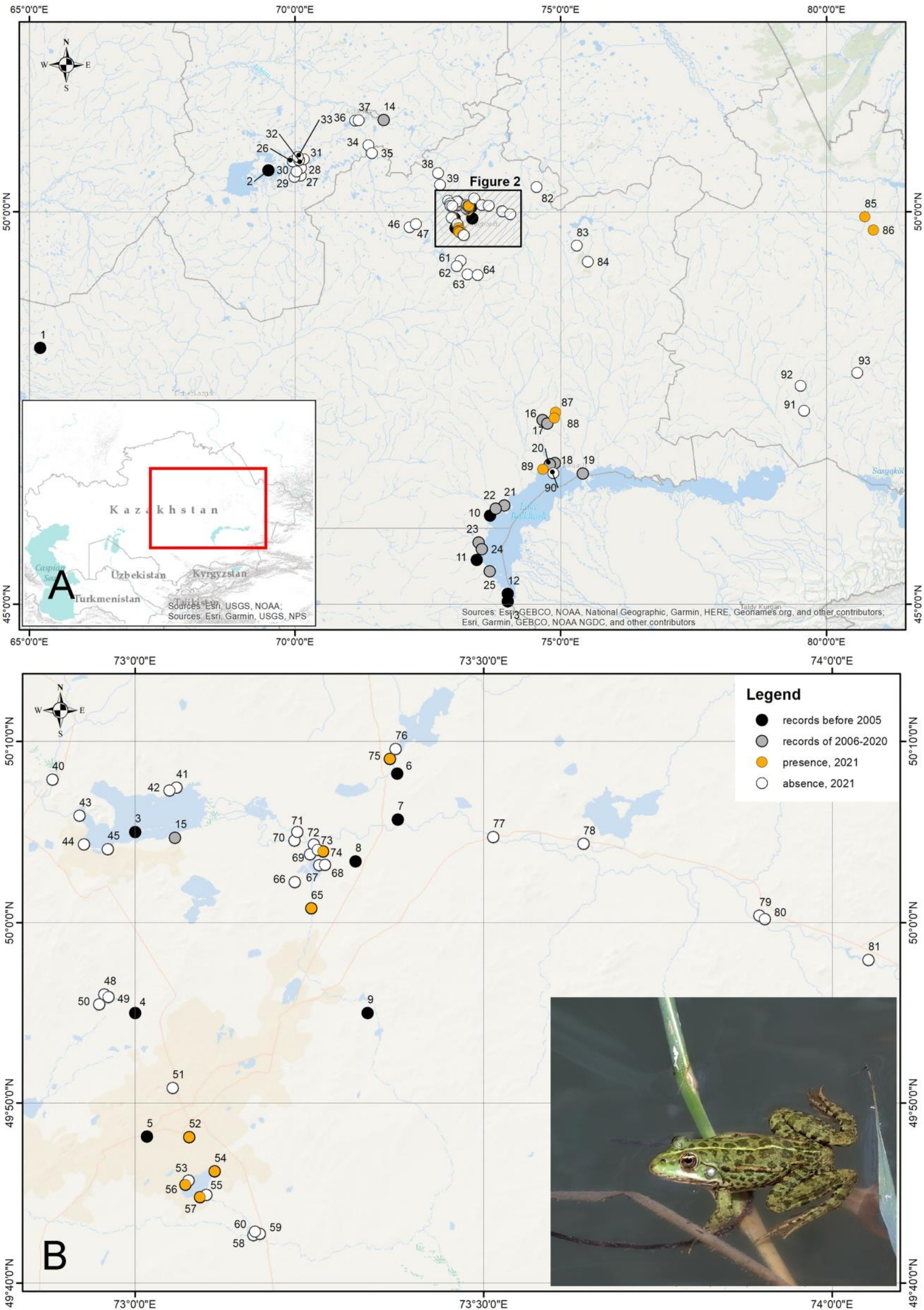

Fig. 1. Distribution data of the marsh frogs in the Kazakh Upland collected during the last 70 years $(A)$ with the record details of the inset with oblique shading (B). The data obtained before 2005 were taken from [8].

The data for the period from 2006-2020 are from an unpublished database of the first author; and the data for 2021 were obtained by the authors of the present paper (APPENDIXI) 


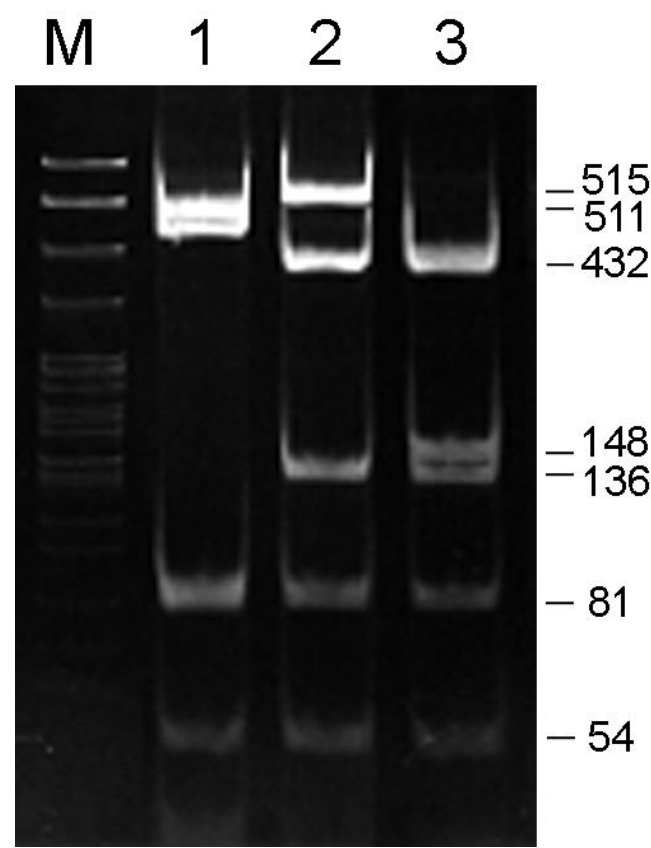

Fig. 2. Electropherogram of the products of restriction of mtDNA of ND2 gene of the two marsh frog forms

by endonuclease BsuRI (HaellI). Wells of the gel: no. 1 are "Balkhash"; nos. 2, 3 are P. cf. bedriagae. Numbers on the right are the lengths of the mtDNA fragments, base pairs. $M$ is the marker of the molecular length

\section{Results}

\section{Distribution}

Central Kazakhstan Main Watershed Upland. In 2021, in the Nura River Basin, the habitat of marsh frogs was recorded only in the middle stream of the river in Karaganda, a suburban area and at several points between the cities of Karaganda and Temirtau. The frequency of encounters with both adults and juveniles (tadpoles and juveniles with access to land) was, with rare exceptions, low. In the first half of June, rare adult frogs were observed in the floodplain of the main channel of the River Nura, flowing in the Central Park of Karaganda (see Fig. 1,B: 52). In the southern part of the city, on the Fedorovskoe Reservoir, frogs were relatively numerous: $20-30$ adult frogs per $100 \mathrm{~m}$ of the shore (see Fig. 1,B: 54, 56, 57). On July 21 at the fish-farm ponds near the village of Solonichki to the east of the city of Temirtau only three juveniles were recorded; and on 7 August on the River Solonka, which flows into the same ponds, distinguishable frog voices were heard and one adult was encountered (see Fig. 1,B: 65, 74). A day later, low density tadpoles and metamorphoses $\left(3 \mathrm{sp} . / 4 \mathrm{~m}^{2}\right)$ were recorded in the southern section of the Irtysh-Karaganda Channel which is closest to the city (reservoir of outlet no. 29) (see Fig. 1,B: 75; 3A).
In other water bodies of the middle stretches of the River Nura, the search for frogs was unsuccessful. We failed to find them in the main channel in the vicinity of the villages of Romanovka, Akhmet, Yntymak, and Kyzylzhar located west of Karaganda; in the basin of a large left tributary of the River Nura, the River Sherubai-Nura (the rivers Sokyr and Karagandinka; the Chkalovskoe Reservoir; and the reservoir near the Gagarinskoe summer cottages); in the Oshagandy River, the right tributary of the River Nura; and in the River Nura main channel near the village of Petrovka (east of Temirtau) (see Fig. 1,A,B: 34, 35, 39-42, 46-50, 58-60, 77).

Our inspection of the shores of the Samarkand Reservoir located north of Temirtau, where these frogs were common in the 1990s, also did not yield positive results (see Fig. 1,B: 41-45). The frogs were absent in the mine waters of Karaganda, where they lived in a large number in the eighties and nineties (Atakhanova, pers. comm.; our data). On the Samarkandskoe Reservoir, only Rana arvalis has been recorded in high numbers. We did not find marsh frogs in the lower stream of the River Nura; on the fresh and brackish lakes of the TengizKurgaldzhin Depression (see Fig. 1,A: 26-37); and on a stretch of the River Ishim with its tributaries (see Fig. 1,A: 36-38). The frogs were absent in the upper stream of the River Nura, including its tributaries on the transect between the villages of Sartobe and Sheshenkara (see Fig. 1,B: 78-81); in the Karkaralinsk Mountains (see Fig. 1,A: 83, 84) and on the River Ayaguz with its right tributary, the Aigyz, flowing from the Akshatau Mountains (see Fig. 1,A: 91-93), all of these being examined for the first time.

Kokchetau Upland and adjacent plains. Only $R$. arvalis was recorded in all the lakes and rivers of the Shchuchinsko-Borovskoe Lake System.

The northern part of Chu-Ili Lowlands and the denudation plains of the Kazakh Upland. In early May, travelling along the left bank of Lake Balkhash, we recorded the frogs' voices only on the Shubartubek Peninsula (see Fig. 1,A: 89; 3B). North of Balkhash, the frogs were still living in the ponds of the piedmont of Mount Bektau-Ata, where the friendly polyphonic choirs resounded in the first part of May. A few years earlier, the frogs had successfully taken over a spring with a small overflow near these ponds (Fig. 3,C). However, it froze solid with the strong drop in air temperature and severe freezing conditions in March 2021. In the floodplain of the River Shar (the left tributary of the River Irtysh) the frogs were common even in late August (see Fig. 3,D). We counted 1-3 adults and twice as many juveniles along short coastal stretches of 20-30 m. 

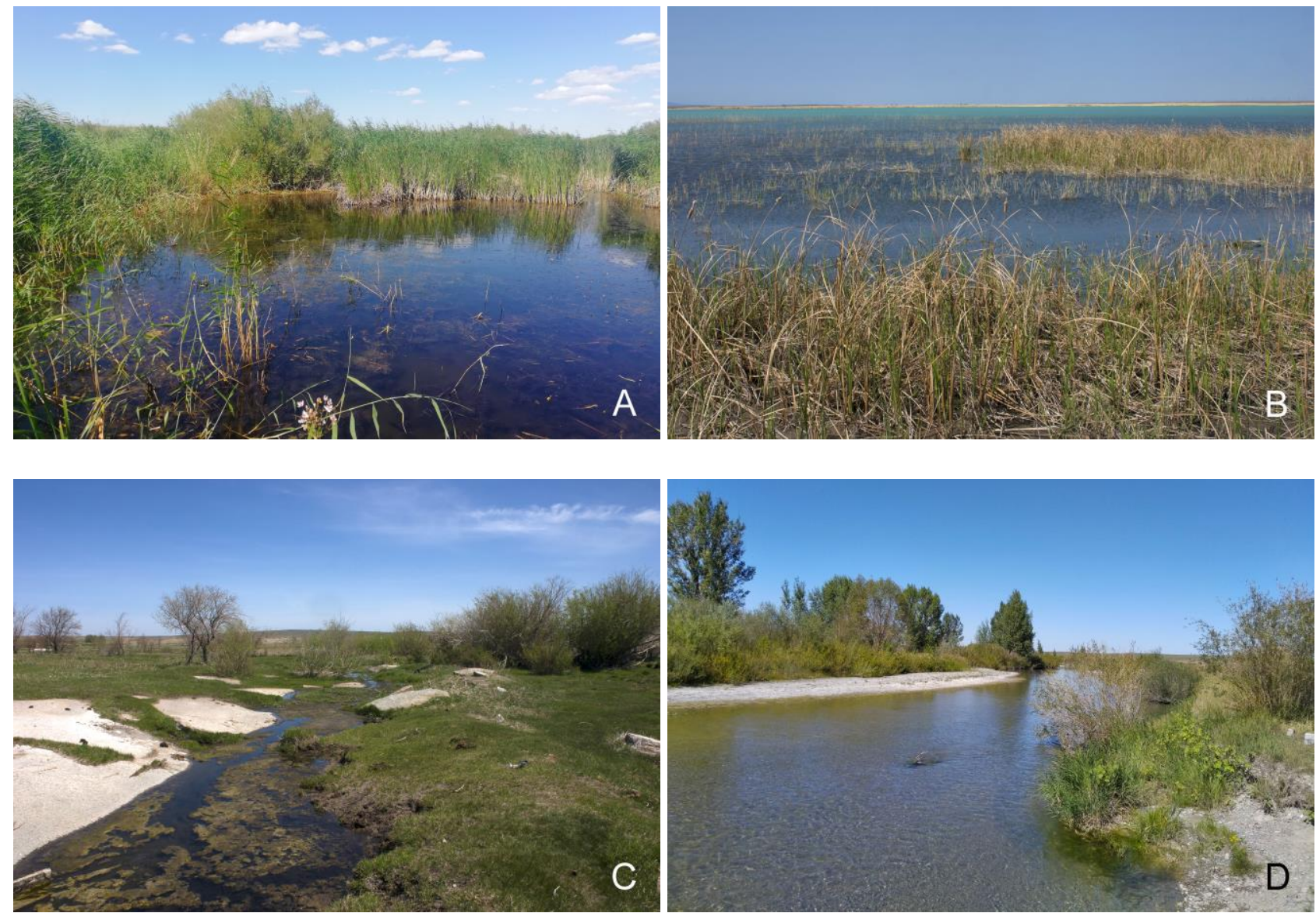

Fig. 3. The habitats of the marsh frogs in the Kazakh Upland:

A - Irtysh-Karaganda Channel, July 22, 2021; B - Shubartubek Peninsula, north-west bank of the Balkhash Lake, May 15, 2021; C - the spring at the piedmont of Bektau-Ata Mount (north of Balkhash Lake) with shallow and poor vegetation which is not typical for the marsh frogs, May 12, 2021; $D$ - the bank of the Shar River (left tributary of the Irtysh River), south of Semipalatinsk, August 24, 2021. Photo by: A. Kaptyonkina (A), T. Dujsebayeva (B, C), V. Khromov (D)

\section{The genetic composition of the complex}

According to the results of our molecular genetic analysis of the ND2 gene, two of the three forms noted for Kazakhstan were found in the area of the Kazakh Uplands - Anatolian and Balkhash.

The sample from the Northern Balkhash Lake Region (S13, at the foot of Mount Bektau-Ata, $\mathrm{n}=6$ ) was identified as the form P. cf. bedriagae (Fig. 4). The same form was found on the River Bukpa near Karaganda City ( $88 ; \mathrm{n}=1)$, which flows into the Fedorovskoe Reservoir (S10; n = 1). However, the "Balkhash" form lived in the Fedorovskoe Reservoir itself ( $S 9 ; n=1)$. The marsh frogs from the western coast of the Balkhash Lake (S14; Minaral Peninsula, $\mathrm{n}=1$ ) and the River Shar (the left tributary of the Irtysh River southeast of Semipalatinsk City) (S4; $n=5)$ were identified as the "Balkhash" form. Both forms were found in the IrtyshKaraganda Channel (S12; oxbow Tuzdy, $\mathrm{n}=3$ ), Karaganda fish hatchery $(\mathrm{S} 11 ; \mathrm{n}=3)$, and in the
Ust-Kamenogorsk City and its environs (S6, 7; $\mathrm{n}=2$ ) (see Fig. 4).

Samples taken from frogs from reservoirs outside the Kazakh Upland showed the following picture. To the north of the KU, in the Kostanay (S1; Toguzak river, $\mathrm{n}=3$ ) and Pavlodar (S2; Pavlodar, $\mathrm{n}=1$ ) regions, the form $P$. cf. bedriagae was found. It was also found in the Uba River Basin (S5; Vavilonka River, $\mathrm{n}=1$ ) - in the right tributary of the River Irtysh, which flows into the Irtysh at the middle elevation between Semipalatinsk and Ust-Kamenogorsk.

In reservoirs on the River Mukur in the vicinity of Semipalatinsk, both forms of the marsh frog also live (S3; $\mathrm{n}=5$ - both forms). To the south within the Balkhash-Ili depression (the environs of the Kishtobe settlement on the Karatal River $(\mathrm{S} 15 ; \mathrm{n}=4)$; the Ainabulak settlement in the Ili River valley $(\mathrm{S} 16 ; \mathrm{n}=1)$; in Almaty ( $\mathrm{S} 17$; the Baum grove, $\mathrm{n}=2$ ); and on the shores of Lake Issyk-Kul (S18; Kyrgyzstan, $\mathrm{n}=1)$ - only the Balkhash form has been noted so far (see Fig. 4). 


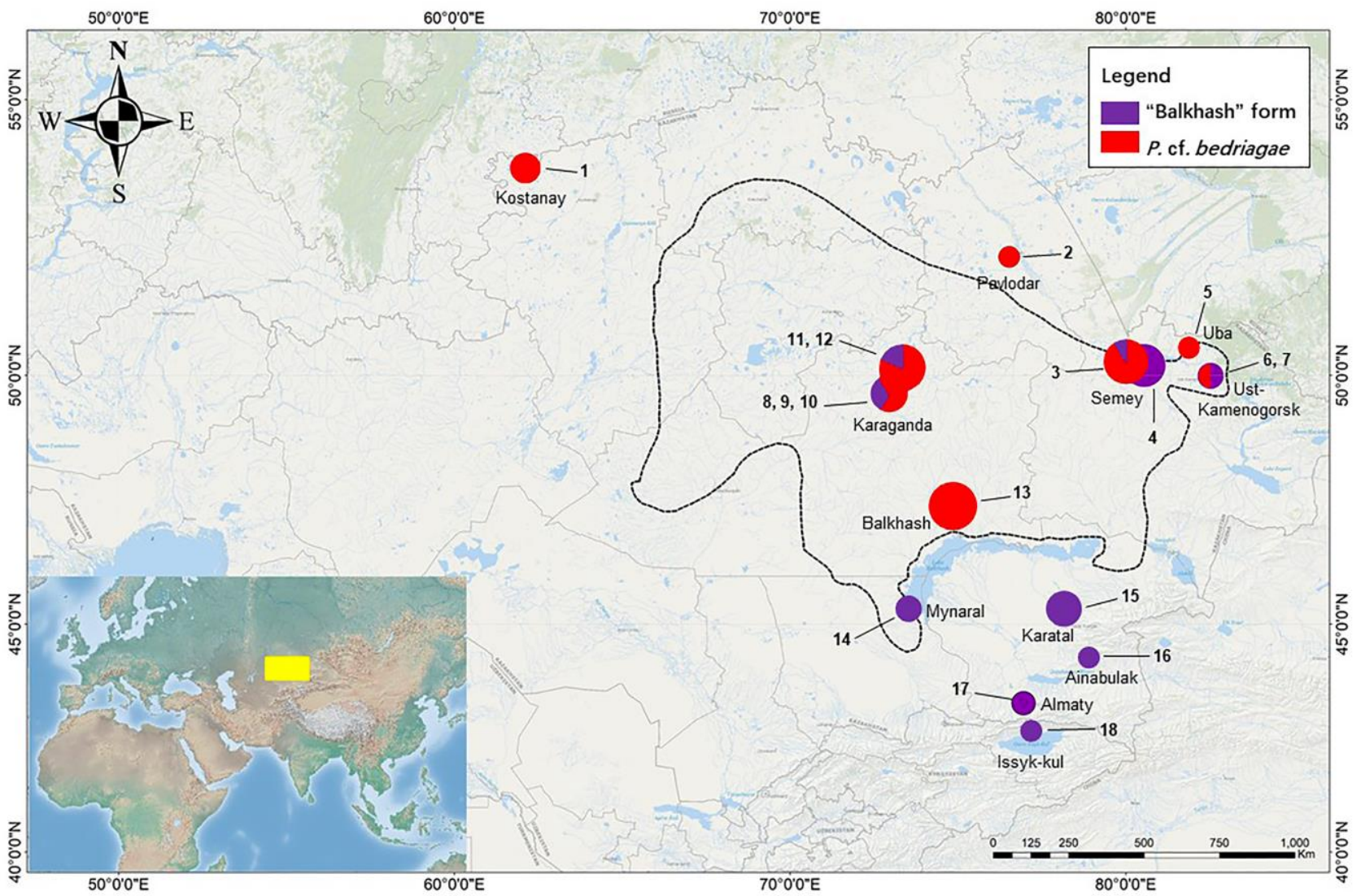

Fig. 4. The areas highlighted by yellow color (incut) and by dotted line (main picture) are the boundaries of the Central Kazakhstan Upland. The inserted map represents ND2 haplogroups based on molecular-genetic analysis, whereas the red circles represent the Anatolian form, $P$. cf. bedriagae, and the purple color the Balkhash native form.

The size of of the circle demonstrates the sampling size, whereas the numbers indicate the sampling sites

\section{Discussion}

\section{Recent distribution of the marsh frogs and possible reasons for its retreat in the Kazakh Upland}

Until the middle of the 20th century, marsh frogs did not inhabit the Kazakh Upland. The conditions present in the depths of the Eurasian continent, such as the continental climate, poorly developed hydrographic network, and low desalination; and the geographical barriers presented by these vast arid, and practically waterless spaces all militated against the natural expansion of these amphibians within the area. The "trigger" for the appearance and expansion of the marsh frogs in KU can definitely be considered to be human activity specifically, the release of frogs from universities and biological and medical institutes where it was kept as a laboratory animal $[8,30]$. The influence of the stocking of pond farms also cannot be excluded. In Karaganda and its environs (the River Bukpa), marsh frogs were already definitely being observed at the beginning of the 1960s or even earlier [9, 31]. Over the next couple of decades in Karaganda and surrounding areas (Solonichki Village and the Samarskoe and Samarkandskoe reser- voirs), the marsh frogs formed abundant and stable populations.

The amphibians widely settled in shallow ponds along the channel stretching from the Karaganda to the Irtysh River (see Fig. 1,B: 3-9). The assumption about the possibility of their settlement downstream of the Nura River and the penetration of frogs into the basin of the Ishim River was proposed by us earlier [8]. This could be facilitated, firstly, by the narrowness of the interfluve of the Nura and the Ishim at the longitude of Nur-Sultan (formerly Astana), an obstacle that could be overcome by frogs in the years of high watering of the territory, and, secondly, construction in the 1970s of the Nura-Ishim Channel. Our assumption was confirmed by the amphibians being recorded in the water bodies of the southern outskirts of NurSultan on June 23, 2009.

The appearance of marsh frogs in the bays of the western coast of Lake Balkhash was first reported by M. N. Korelov [10] (see Fig. 1,A: 10-13). By the end of the first decade of the 21st century, they also inhabited the northern coast of the freshwater part of the lake [12] (see Fig. 1,A: 18-25). In addition, they were recorded in a man-made pond and in small rivers in the area of Mount Bektau-Ata, located $70 \mathrm{~km}$ north of Balkhash [11]. The release 
of marsh frogs in Ust-Kamenogorsk City was carried out into stagnant reservoirs of the city by students of the Ust-Kamenogorsk Pedagogical Institute in the 1960s and 1970s. [1, 8, 30]. Their rapid dispersal down the Irtysh River floodplain took place in the 1980s. and they became a background species of amphibians in the Irtysh floodplain between the cities of Ust-Kamenogorsk and Semipalatinsk, dispersed along many tributaries of the river [32-35].

Thus, by the time of our research, the marsh frogs were known across the reservoirs of the Central Kazakhstan Main Watershed Upland; the Northern Balkhash Region; the northern part of the Chu-Ili Lowlands (the western coast of the Balkhash Lake); and from the watercourses of the peripheral KU plains in the vicinity of UstKamenogorsk City and south of Semipalatinsk City. According to the literature [31] and our own observations, there was no puddle in the vicinity of the cities of Karaganda and Temirtau in the past decades where these frogs were not found. Taking into account a large number of mine reservoirs, including the Fedorovskoe Reservoir, and the presence of temporary or permanent connections between them, the number of amphibians was very high and noticeable to the entire population.

When planning a repeat monitoring of the distribution of the marsh frogs in Kazakhstan, we assumed that its dispersal in the water bodies of the country would have continued. We assumed that this would be the case also for the KU, where the amphibians had demonstrated a really vivid example of their appearance and expansion.

However, our assumptions were proved to be false. Inspecting the KU in May-August 2021, we found that the number of marsh frogs (both adults and offspring) had become noticeably smaller compared to the data of previous decades; and in many water bodies where they had been reliably noticed before, they had disappeared. High density was shown only for the Fedorovskoe Reservoir and on the Shar River (including subadults). In the 1990s, during the breeding season (end of April-May) near the village of Solonichki and along the banks of the Samarkand and Samara reservoirs, the density of frogs had been high (10-15 ind. $\left./ \mathrm{m}^{2}\right)$, even on the very polluted River Bukpa (7-10 ind. $/ \mathrm{m}^{2}$ ) [31]. We recorded only few juvenile individuals only on the site of the pond farm near Solonichki Village; while the frogs were completely absent from the Samarkand Reservoir (see Fig. 1). Interannual fluctuations in the population number could be considered as the reason for the decrease in the abundance of frogs. However, according to our observations, this process began on the central region of the KU as far back as 2014-2015. It proceeded quickly - as at one time the expansion of frogs had taken place here.
It seems that in the late 1950 s - early 1960 s, the successful adaptation and rapid spread of unintentionally introduced amphibians in the KU region were primarily facilitated by climatic factors. The designated period was characterized by a change in the climatic cycle. As can be seen from Fig. 5, the annual precipitation amounts increased significantly and remained above the average level for about ten years. The initial short-term decrease in air temperature was soon replaced by its rise, which significantly exceeded the norm [36, 37]. An increase in the total water content of the area and milder thermal conditions in all probability allowed the frogs to successfully establish themselves and then occupy significant areas.

To support this suggestion, data from the study of the River Nura runnoff can be considered. This river was most successfully developed by marsh frogs in the past [36-38]. In the 60s and 70s, a number of canals were put into operation on the rivers of the Kazakh Upland in order to maintain the flow of the Nura at a higher level. For example, after the construction of the Satpayev's canal in 1973 downstream of the village of Sheshenkara, the annual flow of the Nura increased sharply from $4.77 \mathrm{~m}^{3} / \mathrm{s}$ to $8.39 \mathrm{~m}^{3} / \mathrm{s}(76 \%)$.

An increase in runoff was observed until 1990 (on average by $5.52 \mathrm{~m}^{3} / \mathrm{s}$ ). Later it began to decrease: to $3.27 \mathrm{~m}^{3} / \mathrm{s}$ by 2000 and to $1.22 \mathrm{~m}^{3} / \mathrm{s}$ by 2012, remaining at this level now. Analysis of the situation indicated a correlation between the decrease in runoff (0.97) and climate warming. In addition, the influence of the regulation of the Ishim and Nura channels on the runoff was noted. A decrease in the intensity of floods reduced the total water content of the territory [36] and, obviously, worsened the conditions for the reproduction of amphibians.

From 2008 to 2011, the annual amount of precipitation significantly decreased, and the average temperatures during this period dropped by about $2{ }^{\circ} \mathrm{C}$ below the norm. Such synchronization in meteorological parameters occurred 6-8 years before the noted period of extinction of the species, which coincides with the average lifespan of the marsh frogs [39].

A decrease in air temperature and a decrease in the level of the rivers appears to have had a negative effect not only on the spring reproduction of frogs but also on their overwintering. The marsh frogs overwinter at the bottom of lakes, ponds and swamps in non-freezing water [7], and freezing of shallow water bodies, as, for example, at the spring near Mount Bektau-Ata in March 2021, is destructive for them. An additional negative factor, in our opinion, was the late frosts observed in the last decade immediately after the spring floods. 


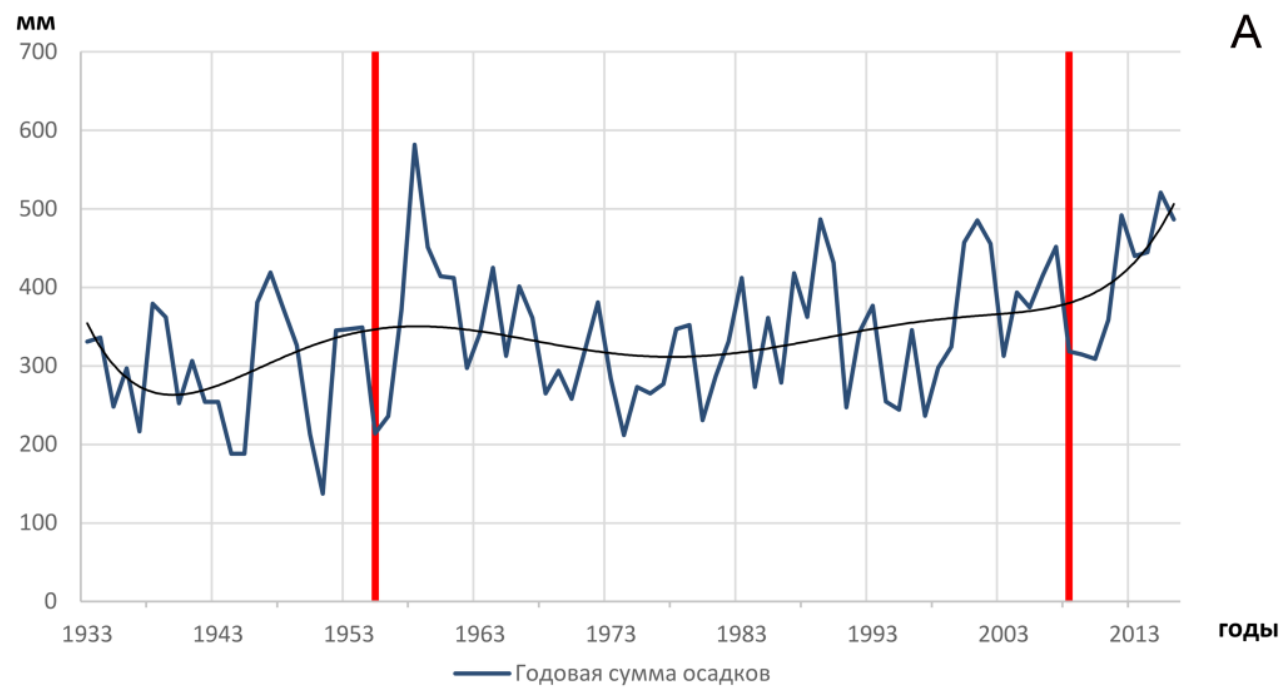

${ }^{\circ} \mathrm{C}$

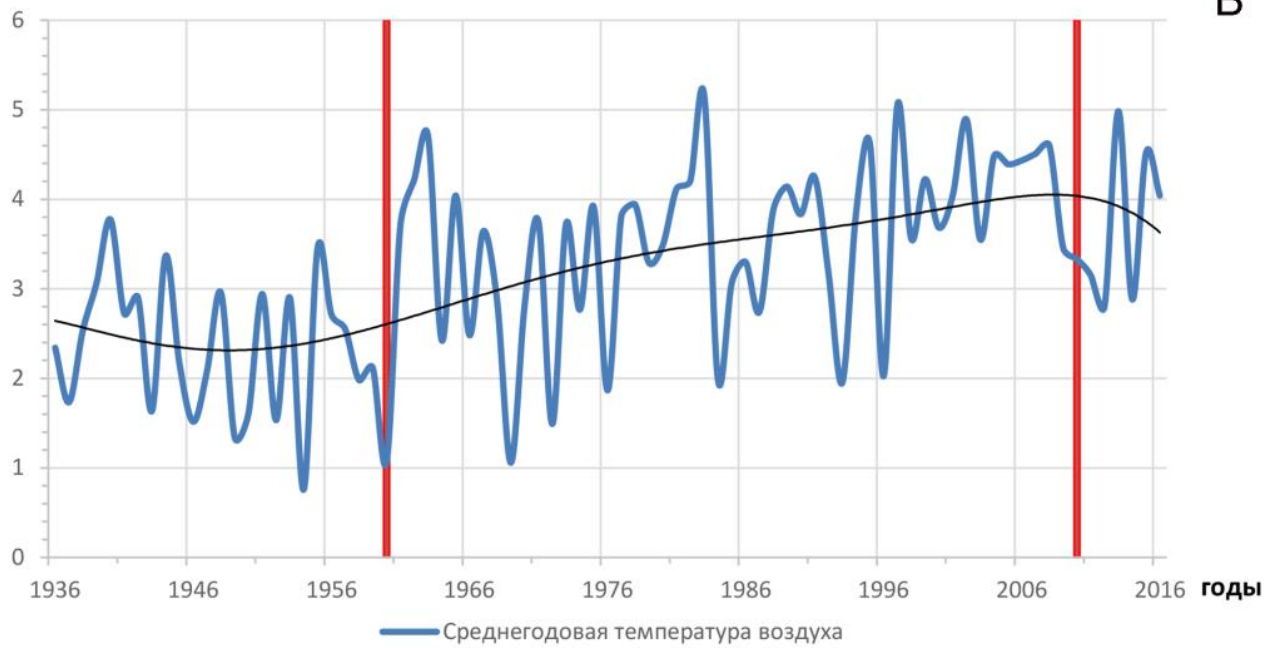

Fig. 5. Annual precipitation (A) and average air temperature (B) for the Karaganda meteorological station according to polynomial analysis data (according to [37] with changes). The red lines indicate the periods of expansion (left) and retreat (right) of the marsh frogs in the Kazakh Upland

The stated assumption about climatic reasons being behind the decrease in the number of marsh frogs on the territory of the Kazakh Upland undoubtedly needs to be confirmed. In particular, the seasonal fluctuations in temperature and precipitation in the region for at least the last ten years and an assessment of their impact on the state of $P$. cf. ridibundus populations require detailed study.

The decrease in the abundance of the marsh frogs on the Balkhash Lake is probably associated with the activity of an alien species - the snakehead (Channa argus). Fishermen and local inspectors confirmed that the number of frogs began to decline after the successful colonization of Balkhash by this fish. The diet of the snakeheads is based on fish, insects, and crustaceans; but it also successfully eats the frogs - both adults and their larvae [40]. Interestingly, the growth in the snakehead population in the Ile-Balkhash Basin was precisely predicted for 2020-2021 [41].
The data on the marsh frog presence along the Shar River (southern of Semipalatinsk City), was first reported by Khromov and Pilguk [34]. According to our observations, it remains a common species in this large tributary of the Irtysh, which has a constant connection with the stable populations from the main riverbed. In the area of the Kokchetau Upland, marsh frogs have never been recorded [42-45]. It appears that this area was probably too cold for thermophilic $P$. ridibundus. The only known indication of marsh frogs being located on the lakes and rivers of the TengizKurgaldzhin Depression in the 1970s seems to be doubtful [46], as well as the fact of their being recorded on the River Kargalinka in the Ulytau Upland [1]. In the first case, incorrect species identification is not excluded, since marsh frogs have not been seen here either before or after the reported identification. In the second case, the location lies on a shallow dry river in the arid western foothills 
of Ulutau Upland, which is a large distance away from any permanent water streams or a stagnant body of water. It is also far from the areas of human economic activity, when artificial relocation of animals can take place.

\section{The genetic composition of the complex}

According to the literature [13, 16, 47] and our unpublished data, the territory of Kazakhstan is inhabited by three forms (mitochondrial lines) of the $P$. ridibundus complex. The Anatolian form ( $P$. cf. bedriagae sensu stricto) is widespread in Western Kazakhstan, approximately up to the Mugodzhar Mountains and Emba River; and also, it is probable, in Northern Kazakhstan, since it has been noted in the adjacent regions of Russia - the provinces of Orenburg, Kurgan and Chelyabinsk [47].

The other two forms - "Syr-Darya" and "Balkhash" - are sister groups (genetic distance (p-distance) $3.1 \pm 0.5 \%)$. The first form inhabits the basin of the River Syr-Darya. The second form was found for the first time in Almaty [16]; and later recorded in several localities from Lake Balkhash in the north to Lake Issyk-Kul in the south. The Anatolian form differs from the "SyrDarya" and "Balkhash" forms by $3.6 \pm 0.6 \%$ and $4.7 \pm 0.6 \%$, respectively.

The present data confirms the assumptions about a wider distribution of the Anatolian form, $P$. cf. bedriagae in Eurasia. It has been identified in the northern and central regions of Kazakhstan in Kostanay Province on the border with Russia; and in the KU (in its central regions and on the southern periphery - the edges of the Balkhash Lake). It seems that it is also widely spreads along the floodplain of the Irtysh River - from the city of Pavlodar to the city of Ust-Kamenogorsk.
The wide distribution of $P$. cf. bedriagae from Asia Minor to Central Asia is obviously due to the highly adaptive nature of this form; and the analysis of its ecological niche is of undoubted interest.

The "Balkhash" form is currently established only on the territory of Kazakhstan. According to the available data, it absolutely dominates in the southeastern territory of the country, including the desert and mountainous regions; and as real data show, it inhabits the territory of the KU (see Fig. 4). Here it lives partly sympatrically with the Anatolian form.

\section{Conclusion}

Significant changes in the spatial and numerical distribution of the marsh frogs in the Kazakh Upland, and the results of the genetic screening of the populations (mostly received for the first time) remain difficult to interpret. The influence of climate on the range and number decline of the marsh frogs is undoubted; but, possibly, partially mediated. According to some information, the native "Balkhash" form was the first in the development of open spaces of the KU. In particular, it was so in the Northern Balkhash Region [11], which now is inhabited by $P$. cf. bedriagae. Climate changes may affect the less adaptive "Balkhash" form more than the Anatolian one, whose broad footprint is felt not only in Europe, but, as shown here, in Asia. Hence, a comparison of the environmental preferences of these forms seems promising. Current ideas for further research include further monitoring of the spatial and numerical distribution of marsh frogs in $\mathrm{KU}$; elucidation of the ways of penetration and dispersal of both forms here; habitat boundaries and delineation of the native "Balkhash" form; the analysis of the nuclear genome; and many others.

\section{References}

1. Kuz'min S.L. Zemnovodnye byvshego SSSR = Amphibians of the former USSR. 2nd ed. Moscow: Tovarishchestvo nauchnykh izdaniy KMK, 2012:370. (In Russ.)

2. Litvinchuk S.N., Ivanov A.Yu., Lukonina S.A. [et al.]. A record of alien Pelophylax species and widespread mitochondrial DNA transfer in Kaliningradskaya Oblast' (the Baltic coast, Russia). BioInvasions Records. 2020;9(3):599-617. doi: 10.3391/bir.2020.9.3.16

3. Kuranova V.N., Yakovlev V.A., Simonov E.P. [et al.]. Diversity, distribution, and conservation status of amphibians in Western Siberia. Populyatsionnaya ekologiya zhivotnykh: Mezhdunar. nauch. konf., posvyashch. pamyati akad. I. A. Shilova = Population ecology of animals: Intern. scientific. conf., dedicated to the memory of acad. I. A. Shilov. Tomsk, 2016;5(3):70. (In Russ.)

4. Lyapkov S.M. Locations and status of marsh frog populations in Kamchatka Vestnik Tambovskogo universiteta. Ser. Estestvennye i tekhnicheskie nauki = Bulletin of Tambov University. Natural sciences and engineering sciences series. 2016:21(5):1821-1824. (In Russ.)

5. Lyapkov S.M., Lyapkov O.A., Titov S.V. Distribution and origin of two forms of the marsh frog Pelophylax ridibundus complex (Anura, Ranidae) in Kamchatka according to the analysis of mitochondrial and nuclear DNA. Zoologicheskiy zhurnal = Zoological journal. 2017;96(11):1384-1391. (In Russ.)

6. Bashinskiy I.V., Osipov F.A., Kuranova V.N. Pelophylax ridibundus - marsh frog. Samye opasnye invazionnye vidy Rossii $($ TOP-100) $=$ The most dangerous invasive species of Russia (Top-100). Moscow: Tovarishchestvo nauchnykh izdaniy KMK, 2018:573-579. (In Russ.) 
7. Iskakova K.I. Zemnovodnye Kazakhstana = Amphibians of Kazahstan. Alma-Ata: Izd-vo AN KazSSR, $1959: 92$. (In Russ.)

8. Dujsebayeva T.N., Berezovikov N.N., Brushko Z.K. [et al.]. Marsh frog (Rana ridibunda Pallas 1771) in Kazakhstan: changes in habitat in the 20th century and modern distribution of the species. Sovremennaya gerpetologiya $=$ Modern herpetology. 2005;3/4:29-59. (In Russ.)

9. Kapitonov V.I. Zhivotnye goroda Karagandy i okrestnostey. Vliyanie antropogennoy transformatsii landshafta na naselenie pozvonochnykh zhivotnykh = Animals of the city of Karaganda and its adjacent territories. Influence of anthropogenic transformation of the landscape on the population of vertebrates. Moscow, 1987;1:233-234. (In Russ.)

10. Korelov M.N. Penetration of the marsh frog into the Balkhash basin. Byulleten' Moskovskogo obshchestva ispytateley prirody. Otdel biologicheskiy = Bulletin of the Moscow Society of Naturalists. Biological series 1953;58(4):33-34. (In Russ.)

11. Dujsebayeva T.N., Chirikova M.A., Zima Yu.A. [et al.]. New data on the distribution of amphibians and reptiles in Kazakhstan: an overview of the first decade of the 21st century Gerpetologicheskie issledovaniya v Kazakhstane $i$ $v$ sopredel'nykh stranakh: sb. st., posvyashch. pamyati K. P. Paraskiva = Herpetological research in Kazakhstan and neighboring countries: collection of articles, dedicated to the memory of K.P. Paraskev. Almaty, 2010:84-99. (In Russ.)

12. Dujsebayeva T.N. Changes in the habitats of some amphibians and reptiles in Kazakhstan in the 20th century: a brief overview and forecast. Selevinia. 2011;19:39-47. (In Russ.)

13. Akin C.., Bilgin S., Beerli P. [et al.]. Geological processes and climate change in the Late Cenozoic determined Phylogeographic patterns of genetic diversity in eastern Mediterranean water frogs. Journal of Biogeography. 2010;37(11):2111-2124. doi: 10.1111/j.1365-2699.2010.02368.x

14. Plötner J., Uzzel T., Beerli P. [et al.]. Genetic divergence and evolution of reproductive isolation in Eastern Mediterranean water frogs. Evolution in Action. Berlin; Heidelberg: Springer-Verlag, 2010:373-403.

15. Hotz H., Beerli P., Uzzell T. [et al.]. Balancing a cline by influx of migrants: a genetic transition in water frogs of Eastern Greece. Journal of Heredity. 2013;(104): 57-71. doi: 10.1093/jhered/ess086

16. Akin Ç. Molecular evolution and phylogeography of the Eastern Mediterranean water frog (Pelophylax) complex: PhD thesis, School of Natural and Applied Sciences of Middle East Technical University. Ankara, 2015.

17. Gvozdetskiy N.A., Mikhaylov N.I. Fizicheskaya geografiya SSSR. Aziatskaya chast': uchebnik dlya universitetov = Physical geography of the USSR. Asian part: textbook for universities. Moscow: Gosudarstvennoe izd-vo geograficheskoy lit-ry, 1963:572. (In Russ.)

18. Visloguzova A.V., Vladimirov N.M., Gus'kova A.I. [et al.]. Rel'ef Kazakhstana (poyasnitel'naya zapiska $k$ Geomorfologicheskoy karte Kazakhskoy SSR masshtaba 1:1 500 000): v 2-kh ch. = Relief of Kazakhstan (explanatory note to the Geomorphological map of the Kazakh SSR on a scale of 1: 1,500,000): in 2 parts.. Alma-Ata: Fylym, 1991;1:176. (In Russ.)

19. Fin'ko E. A. Morphological structure. Ravniny i gory Sredney Azii i Kazakhstana = Plains and mountains of Central Asia and Kazakhstan. Moscow: Nauka, 1975:215-219. (In Russ.)

20. Vilesov E.N., Naumenko A.A., Veselova L.K., Aubekerov B.Zh. Fizicheskaya geografiya Kazakhstana: ucheb. posobie $=$ Physical geography of Kazakhstan: study guide. Almaty: Kazak universiteti, 2009:362. (In Russ.)

21. Alisov B.P. Klimaticheskie oblasti zarubezhnykh stran = Climatic regions of foreign countries. Moscow: Gosudarstvennoe izd-vo geograficheskoy lit-ry, 1950:350. (In Russ.)

22. Vilesov E.N., Guzhavina E.A., Uvarov V.N. To the characteristic of the climate continentality in Kazakhstan. Voprosy gidrologii oroshaemykh zemel' Kazakhstana: sb. nauch. st. = Issues of hydrology of irrigated lands in Kazakhstan: collection of articles. Alma-Ata, 1986:44-54. (In Russ.)

23. Medeu A. R. [ed.]. Natsional'nyy atlas Respubliki Kazakhstan. Tom 1: Prirodnye usloviya $i$ resursy = National Atlas of the Republic of Kazakhstan. Volume 1: Natural Conditions and Resources. 2nd ed., rev. and suppl. Almaty, 2010:150. (In Russ.)

24. Akhmedsafin U.M., Shapiro S.M., Solntsev A.V., Dzhumagulov M.T. Tselinogradskaya oblast'. Gidrogeologicheskie usloviya Kazakhstana = . Alma-Ata: Nauka KazSSR, 1975:57-66. (In Russ.)

25. Akhmedsafin U.M., Shapiro S.M., Zhaparkhanov S.Zh. [et al.]. Tselinograd region. Gidrogeologicheskie usloviya Kazakhstana $=$ Hydrogeological conditions of Kazakhstan. Alma-Ata: Nauka KazSSR, 1975:67-77. (In Russ.)

26. Svarichevskaya Z.A. Geomorfologiya Kazakhstana $i$ Sredney Azii = Geomorphology of Kazakhstan and Central Asia. Leningrad: LGU, 1965:210. (In Russ.)

27. Gvozdetskiy N.A., Nikolaev V.A. Kazakhstan = Kazakhstan. Moscow: Mysl', 1971:295. (In Russ.)

28. Aljanabi S.M., Martinez I. Universal and rapid salt-extraction of high-quality genomic DNA for PCR-based techniques. Nucl. Acids Res. 1997;25(22):4692-4693.

29. Meyer A. Evolution of mitochondrial DNA in fishes. Molecular biology frontiers, biochemistry and molecular biology of fishes. Elsevier Science Publisher, 1993;2:1-38.

30. Samusev I.F. Expansion of the range of the marsh frog Rana ridibunda in Kazakhstan. Izvestiya AN KazSSR. Ser. Biologicheskaya = Proceedings of the Kazakh SSR Academy of Sciences. 1981;(4):27-28. (In Russ.)

31. Atakhanova K.Y., Bigaliev A.B. Current status of amphibian populations in Central Kazakhstan. Amphibian Populations in the Commonwealth of Independent States: Current Status and declines. Moscow, 1995:141-143. 
32. Berdibaeva Zh.Sh. To the biology of the marsh frog (Rana ridibunda) of the East Kazakhstan region. Voprosy gerpetologii $=$ Herpetology issues. Leningrad: Nauka, 1985:24. (In Russ.)

33. Starikov S.V., Prokopov K.P. Herpetofauna of the Upper Irtysh basin. Okhrana okruzhayushchey sredy $i$ prirodopol'zovanie Priirtysh'ya = Environmental protection and nature management of the Irtysh region. Ust'Kamenogorsk, 1990;2:174-178. (In Russ.)

34. Khromov V.A., Pilguk O.N. The amphibian fauna of Semipalatinsk Province, North-Eastern Kazakhstan. Amphibian Populations in the Commonwealth of Independent States: Current Status and declines. Moscow, 1995:144-145.

35. Rakhimbaeva A.K., Khromov V.A. Morphological study of the Green Frog (Rana ridibunda Pallas, 1771) from Eastern Kasakhstan. Abstracts of III Asian Herpetological Meeting. Almaty, 1998:31.

36. Abdrakhimov R.G., Eltay A.G. Characteristics of the annual and maximum flow of the Nura river. Gidrometeorologiya i ekologiya = Hydrometeorology and ecology. 2016;(1):80-86. (In Russ.)

37. Cherednichenko A.V., Cherednichenko V.S. Modern climatic cycles in time series of temperature and precipitation over Kazakhstan. Vestnik VGU. Ser. Geografiya. Geoekologiya = VSU proceedings. Geographical series. Geoecology. 2017;(4):15-33. (In Russ.)

38. Cherednichenko A.V., Cherednichenko A.V., Cherednichenko V.S. Dinamika izmeneniya klimata Kazakhstana = Dynamics of climate change in Kazakhstan. Almaty: Izd-vo KazNU im. al'-Farabi, 2020:501. (In Russ.)

39. Smirina E.M. Age determination and longevity in Amphibians. Gerontology. 1994;40:133-146.

40. Dukravets G.M. Some data on the snakehead Channa argus (Cantor, 1842) in the basin of the river Ili. Izvestiya NAN RK. Ser. biol. = Proceedings of the National Academy of Sciences of the Republic of Kazakhstan. 2007;(2):15-22. (In Russ.)

41. Zhumagaliuly N., Timirkhanov S.R. Snakehead Channa argus warpachowskii (Berg, 1909) in Kazakhstan - the habitat is expanding. Zhivotnyy mir Kazakhstana i sopredel'nykh territoriy: materialy Mezhdunar. nauch. konf. = The fauna of Kazakhstan and adjacent territories: proceedings of the Intern. scientific. conf. Almaty, 2012:248250. (In Russ.)

42. Nikol'skiy A.M. Fauna Rossii i sopredel'nykh stran. Zemnovodnye (Amphibia) = Fauna of Russia and neighboring countries. Amphibians (Amphibia). Petrograd: Tipografiya Rossiyskoy akademii nauk, 1918:309. (In Russ.)

43. Bartenev A.K. On the Zoogeography of the North of Karaganda region Uchenye zapiski Kazakhskogo gosudarstvennogo un-ta = Bulletin of Kazakh State University. Alma-Ata, 1938;1:67-80. (In Russ.)

44. Zima Yu.A., Fedorenko V.A. On new finds of amphibians and reptiles in the Akmola region. Selevinia. 2019;27:51-60. (In Russ.)

45. Dujsebayeva T.N., Arkhipov E.V., Baltasheva S.Zh. At the junction of forests and steppes: the herpetofauna of the State Scientific and Production Enterprise "Burabay" and the tasks of its study. Innovatsii $v$ sokhranenii $i$ ustoychivom razvitii lesnykh ekosistem: Mezhdunar. nauch.-prakt. konf. = Innovations in the conservation and sustainable development of forest ecosystems: Intern. scientific-practical conf. Burabay, 2020:216-220. (In Russ.)

46. Khrokov V.V. Zapovednik Kurgal'dzhino = Reserve Kurgaldzhino. Alma-Ata: Kaynar, 1981:176. (In Russ.)

47. Ivanov A.Yu. Molecular genetic and ecological features of the distribution of cryptic forms of the marsh frog in the eastern part of the habitat. PhD abstract. Penza, 2019:23. (In Russ.)

\section{Cnuсок лumepamyры}

1. Кузьмин С. Л. Земноводные бывшего СССР. 2-е изд. М. : Товарищество научных изданий КМК, 2012.370 с.

2. Litvinchuk S. N., Ivanov A. Yu., Lukonina S. A. [et al.]. A record of alien Pelophylax species and widespread mitochondrial DNA transfer in Kaliningradskaya Oblast' (the Baltic coast, Russia) // BioInvasions Records. 2020. Vol. 9 (3). P. 599-617. doi: 10.3391/bir.2020.9.3.16

3. Куранова В. Н., Яковлев В. А., Симонов Е. П. [и др.]. Разнообразие, распространение, распределение и природоохранный статус земноводных Западной Сибири // Популяционная экология животных : Междунар. науч. конф., посвящ. памяти акад. И. А. Шилова. Томск, 2016. Т. 5, № 3. С. 70.

4. Ляпков С. М. Места находок и состояние популяций озерной лягушки на Камчатке // Вестник Тамбовского университета. Сер. Естественные и технические науки. Т. 21, вып. 5. С. 1821-1824.

5. Ляпков С. М., Ляпков О. А., Титов С. В. Распространение и происхождение двух форм озерной лягушки Pelophylax ridibundus complex (Anura, Ranidae) на Камчатке по данным анализа митохондриальной и ядерной ДНК // Зоологический журнал. 2017. Т. 96, № 11. С. 1384-1391.

6. Башинский И. В., Осипов Ф. А., Куранова В. Н. Pelophylax ridibundus - Озерная лягушка // Самые опасные инвазионные виды России (ТОП-100) / под ред. Ю. Ю. Дгебуадзе, В. Г. Петросян, Л. А. Хляпа. М. : Товарищество научных изданий КМК, 2018. С. 573-579.

7. Искакова К. И. Земноводные Казахстана. Алма-Ата : Изд-во АН КазССР, 1959. 92 с.

8. Дуйсебаева Т. Н., Березовиков Н. Н., Брушко 3. К. [и др.]. Озерная лягушка (Rana ridibunda Pallas 1771) в Казахстане: изменение ареала в ХХ столетии и современное распространение вида // Современная герпетология. 2005. Т. 3/4. С. 29-59.

9. Капитонов В. И. Животные города Караганды и окрестностей. Влияние антропогенной трансформации ландшафта на население позвоночных животных. М., 1987. Ч. 1. С. 233-234.

10. Корелов М. Н. Проникновение озерной лягушки в Балхашский бассейн // Бюллетень Московского общества испытателей природы. Отдел биологический. 1953. Т. 58, вып. 4. С. 33-34. 
11. Дуйсебаева Т. Н., Чирикова М. А., Зима Ю. А. [и др.]. Новые данные по распространению амфибий и рептилий в Казахстане: обзор по первому десятилетию XXI века // Герпетологические исследования в Казахстане и в сопредельных странах : сб. ст., посвящ. памяти К. П. Параскива / под ред. Т. Н. Дуйсебаевой. Алматы, 2010. С. 84-99.

12. Дуйсебаева Т. Н. Об изменении ареалов некоторых земноводных и пресмыкающихся в Казахстане в XX столетии: краткий обзор и прогноз // Selevinia. 2011. Т. 19. С. 39-47.

13. Akin Ç., Bilgin C., Beerli P. [et al.]. Geological processes and climate change in the Late Cenozoic determined Phylogeographic patterns of genetic diversity in eastern Mediterranean water frogs // Journal of Biogeography. 2010. Vol. 37 (11). P. 2111-2124. doi: 10.1111/j.1365-2699.2010.02368.x

14. Plötner J., Uzzel T., Beerli P. [et al.]. Genetic divergence and evolution of reproductive isolation in Eastern Mediterranean water frogs // Evolution in Action / ed. by M. Glaubrecht. Berlin ; Heidelberg : Springer-Verlag, 2010. P. 373-403.

15. Hotz H., Beerli P., Uzzell T. [et al.]. Balancing a cline by influx of migrants: a genetic transition in water frogs of Eastern Greece // Journal of Heredity. 2013. № 104. P. 57-71. doi: 10.1093/jhered/ess086

16. Akin Ç. Molecular evolution and phylogeography of the Eastern Mediterranean water frog (Pelophylax) complex : $\mathrm{PhD}$ thesis, School of Natural and Applied Sciences of Middle East Technical University. Ankara, 2015.

17. Гвоздецкий Н. А., Михайлов Н. И. Физическая география СССР. Азиатская часть : учебник для университетов. М. : Государственное изд-во географической лит-ры, 1963. 572 с.

18. Вислогузова А. В., Владимиров Н. М., Гуськова А. И. [и др.]. Рельеф Казахстана (пояснительная записка к Геоморфологической карте Казахской ССР масштаба 1:1 500 000) : в 2-х ч. Алма-Ата : Ғылым, 1991. Ч. 1. $176 \mathrm{c}$.

19. Финько Е. А. Морфоструктура // Равнины и горы Средней Азии и Казахстана. М. : Наука, 1975. С. $215-219$.

20. Вилесов Е. Н., Науменко А. А., Веселова Л. К., Аубекеров Б. Ж. Физическая география Казахстана : учеб. пособие / под ред. А. А. Науменко. Алматы : Казак университеті, 2009. 362 с.

21. Алисов Б. П. Климатические области зарубежных стран. М. : Государственное изд-во географической литры, 1950.350 с.

22. Вилесов Е. Н., Гужавина Е. А., Уваров В. Н. К характеристике континентальности климата Казахстана // Вопросы гидрологии орошаемых земель Казахстана : сб. науч. ст. Алма-Ата, 1986. С. 44-54.

23. Национальный атлас Республики Казахстан. Том 1: Природные условия и ресурсы / под ред. А. Р. Медеу. 2-е изд., перераб. и доп. Алматы, 2010. 150 с.

24. Ахмедсафин У. М., Шапиро С. М., Солнцев А. В., Джумагулов М. Т. Целиноградская область // Гидрогеологические условия Казахстана / под ред. У. М. Ахметсафина. Алма-Ата : Наука КазССР, 1975. С. 57-66.

25. Ахмедсафин У. М., Шапиро С. М., Жапарханов С. Ж. [и др.]. Карагандинская область // Гидрогеологические условия Казахстана / под ред. У. М. Ахметсафина. Алма-Ата : Наука КазССР, 1975. С. 67-77.

26. Сваричевская 3. А. Геоморфология Казахстана и Средней Азии. Л. : ЛГУ, 1965. 210 с.

27. Гвоздецкий Н. А., Николаев В. А. Казахстан. М. : Мысль, 1971. 295 с.

28. Aljanabi S. M., Martinez I. Universal and rapid salt-extraction of high-quality genomic DNA for PCR-based techniques // Nucl. Acids Res. 1997. Vol. 25 (22). P. 4692-4693.

29. Meyer A. Evolution of mitochondrial DNA in fishes // Molecular biology frontiers, biochemistry and molecular biology of fishes / ed. by P. W. Hochachka, T. P. Mommsen. Elsevier Science Publisher, 1993. Vol. 2. P. 1-38.

30. Самусев И. Ф. Расширение ареала озерной лягушки Rana ridibunda в Казахстане // Известия АН КазССР. Сер. Биологическая. 1981. № 4. С. 27-28.

31. Atakhanova K. Y., Bigaliev A. B. Current status of amphibian populations in Central Kazakhstan // Amphibian Populations in the Commonwealth of Independent States: Current Status and declines / ed. by S. L. Kusmin, C. K. Dodd, M. M. Pilguk. M., 1995. P. 141-143.

32. Бердибаева Ж. Ш. К биологии озерной лягушки (Rana ridibunda) Восточно-Казахстанской области // Вопросы герпетологии. Л. : Наука, 1985. С. 24.

33. Стариков С. В., Прокопов К. П. Герпетофауна бассейна Верхнего Иртыша // Охрана окружающей среды и природопользование Прииртышья. Усть-Каменогорск, 1990. Ч. 2. С. 174-178.

34. Khromov V. A., Pilguk O. N. The amphibian fauna of Semipalatinsk Province, North-Eastern Kazakhstan // Amphibian Populations in the Commonwealth of Independent States: Current Status and declines / ed. by S. L. Kusmin, C. K. Dodd, M. M. Pilguk. M., 1995. P. 144-145.

35. Rakhimbaeva A. K., Khromov V. A. Morphological study of the Green Frog (Rana ridibunda Pallas, 1771) from Eastern Kasakhstan // Abstracts of III Asian Herpetological Meeting. Almaty, 1998. P. 31.

36. Абдрахимов Р. Г., Елтай А. Г. Характеристики годового и максимального стока реки Нура // Гидрометеорология и экология. 2016. № 1 (80). С. 80-86.

37. Чередниченко А. В., Чередниченко В. С. Современные климатические циклы во временных рядах температуры и осадков над Казахстаном // Вестник ВГУ. Сер. География. Геоэкология. 2017. № 4. С. 15-33.

38. Чередниченко А. В., Чередниченко А. В., Чередниченко В. С. Динамика изменения климата Казахстана. Алматы : Изд-во КазНУ им. аль-Фараби, 2020. 501 с.

39. Smirina E. M. Age determination and longevity in Amphibians // Gerontology. 1994. Vol. 40. P. $133-146$.

40. Дукравец Г. М. Некоторые данные о змееголове Channa argus (Cantor, 1842) в бассейне р. Или // Известия НАН РК. Сер. биол. 2007. № 2. С. 15-22. 
41. Жумагалиулы Н., Тимирханов С. Р. Змееголов Channa argus warpachowskii (Berg, 1909) в Казахстане ареал расширяется // Животный мир Казахстана и сопредельных территорий : материалы Междунар. науч. конф. Алматы, 2012. С. 248-250.

42. Никольский А. М. Фауна России и сопредельных стран. Земноводные (Amphibia). Петроград : Типография Российской академии наук, 1918. 309 с.

43. Бартенев А. К. К вопросу о зоогеографии севера б. Карагандинской области // Ученые записки Казахского государственного ун-та. Алма-Ата, 1938. Т. 1. С. 67-80.

44. Зима Ю. А., Федоренко В. А. О новых находках амфибий и рептилий в Акмолинской области // Selevinia. 2019. T. 27. С. 51-60.

45. Дуйсебаева Т. Н., Архипов Е. В., Балташева С. Ж. На стыке лесов и степей: герпетофауна ГНПП «Бурабай» и задачи ее изучения // Инновации в сохранении и устойчивом развитии лесных экосистем : Междунар. науч.-практ. конф. Бурабай, 2020. С. 216-220.

46. Хроков В. В. Заповедник Кургальджино. Алма-Ата : Кайнар, 1981. 176 с.

47. Иванов А. Ю. Молекулярно-генетические и экологические особенности распространения криптических форм озерной лягушки в восточной части ареала : автореф. дис. ... канд. биол. наук. Пенза, 2019. 23 с. 


\section{List of the records of the marsh frogs (Pelophylax ridibundus complex) in the Central Kazakhstan (Kazakh Upload) known until 2021 (black and grey circles) and the results of 2021 fieldwork with indication to presence (orange circles) and absence (white circles) of the amphibians (see Figure 2) (numeric marked in bold indicate the sites inhabited by marsh frogs)}

\section{Records before 2005:}

1 - Karaganda Prov., Kargalinka River, 48.31673N, 65.20055E, 1991-1992;

2 - Akmolinsk Prov., lakes and rivers of the Tengiz-Kurgaldzhin Depression (lakes Tengiz and Kurgaldzhino, rivers Nura and Kulanutpes), $50.5 \mathrm{~N}, 69.5 \mathrm{E}, 1981$;

3 - Nura River Valley in the vicinity of Karaganda City (Solonichki Village, reservoirs Samarskoe and Samarkandskoe), 50.08333N, 73.0E;

4 - Karaganda City and Bukpa River in its vicinity, 49.91666N, 73.0E;

5 - Karaganda Prov., Nura River in Karaganda City, 49.802306N, 73.016778E, 1993;

6 - Karaganda Prov., Irtysh-Karaganda Channel, 50.137017N, 73.376055E;

7 - Ibid, 50.094753N, 73.37672E;

8 - Ibid, 50.056261N, 73.316096E;

9 - Karaganda Prov., ponds along the IrtyshKaraganda Channel, 49.91666N, 73.33333E;

10 - western coast of Balkhash Lake, Saryshagan Gulf, 46.16666N, 73.66666E;

11 - western coast of Balkhash Lake, Karakamys Gulf, 45.58333N, 73.41666E;

12 - southwestern angle of Balkhash Lake after Chiganak Village, 45.13333N, 74,00000E, 20-21.06.1958;

13 - southern angle of Balkhash Lake, Burubaital Village vicinity, $45.03333 \mathrm{~N}, 74.0 \mathrm{E}$.

Records for the period 2006-2020:

14 - eldress in the south vicinity of Nur-Sultan City, Michurino Village vicinity, 51.10021N, 71.66686E, 23.06.2009;

15 - near Temirtau Town, semi-insulated sedimentation tank, outlet channel in the eastern town vicinity， 50.078056N， 73.057222E，June-July 2006;

16 - the pond near the south foothill of BektauAta Mount, 47.35578N, 74.7465E, 04.05.2008;

17 - Bektau-Ata Mount foothills, 47.357665N, 74.74928E, 02.06.2015;

18 - Balkhash Town, 46.8N, 74.81667E, 27.04.2007;

19 - Ortaderessin Village vicinity, 46.71666N, 75.41666E, 03.05.2008;

20 - Torangylyk Village vicinity, $46.80242 \mathrm{~N}$, 74.81537E, 27.04.2007;
21 - Tasaral Village vicinity, 46.30083N, 73.93505E, 26.04.2007;

22 - Kosagash Peninsula, $5 \mathrm{~km}$ southwest of Eskar Lake, 46.26043N, 73.77487E, 26.04.2007;

23 - Kashkateniz Gulf, 45.81653N,

73.45552E, 26.04.2007;

24 - south of Kashkateniz Gulf, 45.72712N, 73.51402E, 26.04.2007; 05.05.2008;

25 - coast of small lake on the Minaral Peninsula, 45.435N, 73.66333E, 26.04.2007.

Our data for 2021:

26 - Nura River in the Kurgaldzhin Village, 50.59572N, 70.01487E, 10.07.2021;

27 - Birtaban (=Taban) Lake, 50.449623N, 70.018777E, 10.07.2021;

28 - Balyksor Lake (salty), 50.555344N, 70.034193E, 10.07.2021;

29 - Shalkar Lake, 50.418431N, 69.9857E, 12.07.2021;

30 - gulf of the Birtaban (=Taban) Lake, 50.482924N, 70.028636E, 13.07.2021;

31 - Nura River, 50.622565N, 70.088347E, 24.08.2021;

32 - Ibid, 50.620548N, 70.07422E, 24.08.2021;

33 - Ibid, 50.619421N, 70.057877E, 24.08.2021;

34 - Nura River in the Romanovka Village, 50.799225N, 71.377717E, 24.08.2021;

35 - Nura River in Akhmet Village vicinity, 50.703762N, 71.444249E, 25.08.2021;

36 - Mukyr Lake, 51.091373N, 71.130703E, 11.07.2021;

37 - Kozikosh River, 51.094262N, 71.197247E, 11.07.2021;

38 - Batbakty Village, 50.463611N, 72.688778E, 06.05.2021;

39 - Oshagandy Village vicinity, 50.323667N, 72.727861E, 06.05.2021;

40 - reservoir near the summer cottages "Gagarinskoe", Temirtau Town vicinity, $50.1315 \mathrm{~N}$, 72.881305E, 13.05.2021;

41 - northern coast of Samarkandskoe Reservoir, fishing industry, $50.124158 \mathrm{~N}, 73.059235 \mathrm{E}$, 13.05.2021;

42 - Ibid, 50.121413N, 73.04924E, 24.07.2021;

43 - coast of Samarkandskoe Reservoir near Temirtau Town, 50.098198N, $72.920415 \mathrm{E}$, 12.07.2021;

44 - Ibid, 50.071874N,72.926505E, 12.07.2021; 
45 - Ibid, 50.06741N, 72.960921E, 12.07.2021;

46 - Nura River near Intymak Village, 49.810737N, 72.152501E, 26.08.2021;

47 - Kubisay River near Kizilzhar Village, road spills, 49.848455N, 72.276367E, 26.08.2021;

48 - Chkalovskoe Reservoir, the second tributary of Karagandinka River, 49.933717N, 72.955605E, 28.06.2021;

49 - Ibid, 49.931336N, 72.961552E, 29.06.2021;

50 - Chkalovskoe Reservoir, 49.924521N,

72.948659E, 29.06.2021;

51 - main waters, Furmanov Str., Karaganda

City, 49.847388N, 73.054035E, 12.07.2021;

52 - Central Park, Karaganda City, 49.801982N,

73.077676E, 04.06.2021;

53 - Fedorovskoye Reservoir, 49.757727N,

73.072004E, 12.07.2021;

54 - Ibid, 49.770153N, 73.114171E, 12.07.2021; 55 - Ibid, 49.746283N, 73.093057E, 12.07.2021;

56 - Ibid, 49.757712N, 73.072095E,

12.07.2021;

57 - Ibid, 49.746283N, 73.093057E, 12.07.2021; 58 - Sokyr River, 49.711025N, 73.169814E, 30.06.2021;

59 - Ibid, 49.714375N, 73.172606E, 01.07.2021; 60 - Ibid, 49.714347N, 73.172002E, 01.07.2021;

61 - Zhamanzhol River, 49.398306N,

73.113515E, 02.07.2021;

62 - Ibid, 49.387256N, 73.116394E, 02.07.2021;

63 - Deripsal Village vicinity, 49.229444N,

73.24275E, 14.06.2021;

64 - Kizilkoy Village, 49.2225N, 73.43567E,

14.06.2021;

65 - Solonka River, 50.012995N, 73.252812E,

07.08.2021;

$66-$ Solonichki Village, 50.037286N,

73.229204E, 21.07.2021;

67 - Karaganda fish hatchery near Solonichki

Village, 50.052821N, 73.264172E, 21.07.2021;

68 - Ibid, 50.052917N, 73.272181E, 21.07.2021;

69 - Ibid, 50.062607N, 73.2509264E, 21.07.2021;

70 - Ibid, 50.075332N, 73.228572E, 21.07.2021;

71 - Nura River, 50.083133N, 73.232557E,

21.07.2021;
72 - Ibid, 50.071837N, 73.256355E, 21.07.2021;

73 - Karaganda fish hatchery near Solonichki

Village, 50.066735N, 73.261777E, 21.07.2021;

74 - Ibid, 50.065398N, 73.269793E, 21.07.2021;

75 - Irtysh-Karaganda Channel, Tuzdi eldress,

50.150411N, 73.365463E, 22.07.2021;

76 - Irtysh-Karaganda Channel, Tuzdinskoe

Reservoir, 50.159559N, 73.37346E, 22.07.2021;

77 - Nura River, 50.078665N, 73.513483E, 23.07.2021;

78 - the eldress of Sheshenkara River, $50.072368 \mathrm{~N}, 73.643165 \mathrm{E}, 22.07 .2021$;

79 - Sheshenkara River, 50.006294N,

73.895584E, 22.07.2021;

80 - Ibid, 50.002933N, 73.903359E, 22.07.2021;

81 - Ibid, 49.965522N, 74.051984E, 22.07.2021;

82 - Akzhar Village, dam, 50.297767N, 74.545596E, 27.08.2021;

83 - Karkaralinsk Mountains, Betalys Lake, 49.5833N, 75.3E, 13.06.2021:

84 - Karkaralinsk Mountains, Big Lake, 49.388346N, 75.511899E, 12.06.2021;

85 - Shar River south of Uzinshal Village, 49.934952N, 80.720169E, 24.08.2021;

86 - Shar River in $5 \mathrm{~km}$ southeast of Suiykbulak railway station, $49.77453 \mathrm{~N}, 80.88277 \mathrm{E}$, 24.08.2021;

87 - pond near the eastern foothills of BektauAta Mount, 47.5N, 74.90083E, 05.05.2021;

$\mathbf{8 8}$ - spring in the site Karabuta, eastern foothills of Bektau-Ata Mount, 47.427N, 74.879638E, 05.05.2021;

89 - Shubartubek Peninsula, 46.768888N, 74.661888E, 15.06.2021;

90 - Torangalyk Peninsula, 46.7614N, 74.82812E, 15.06.2021;

91 - Ayaguz River south of confluence with Aigyz River, 47.59652N, 79.57767E, 25.08.2021;

92 - Aigyz River (right tributary of Ayaguz River), 47.77354N, 79.50389E, 26.08.2021;

93 - Ayaguz River in the southwestern vicinity of Ayaguz, 47.94217N, 80.39898E, 24.08.2021. 
List of specimens of Pelophylax ridibundus complex examined in this study for molecular-genetic analysis ( $N$, number of the samples)

\begin{tabular}{|c|c|c|c|c|c|}
\hline Taxon & Locality & $\begin{array}{l}\text { Voucher } \\
\text { code }\end{array}$ & Latitude & Longitude & $\mathrm{N}$ \\
\hline P. cf. bedriagae & $\begin{array}{l}\text { North coast of Balkhash Lake, } \\
\text { Bektau-Ata Mount }\end{array}$ & TD 1-6 & 47.42283 & 74.87450 & 6 \\
\hline P. cf. bedriagae & $\begin{array}{l}\text { Kostanay Prov., Toguzak River, } \\
\text { Verenka Village vicinity }\end{array}$ & AT $1-3$ & 53.78223 & 62.14509 & 3 \\
\hline P. cf. bedriagae & Karaganda Prov., Bukpa River & AK-1 & 49.74628 & 73.09305 & 1 \\
\hline P. cf. bedriagae & Karaganda Prov., Fedorovskoe Reservoir & $\mathrm{AK}-2$ & 49.77015 & 73.11417 & 1 \\
\hline "Balkhash" form & $\begin{array}{l}\text { Karaganda Prov., Fedorovskoe Reservoir } \\
\text { vicinity }\end{array}$ & AK-3 & 49.75771 & 73.07209 & 1 \\
\hline $\begin{array}{l}\text { "Balkhash" + } \\
P . \text { cf. bedriagae }\end{array}$ & $\begin{array}{l}\text { East Kazakhstan Prov., Mukur River, } \\
\text { Semipalatinsk City vicinity }\end{array}$ & V9-15 & 50.2457 & 80.0524 & 5 \\
\hline "Balkhash" form & $\begin{array}{l}\text { East Kazakhstan Prov., left shore } \\
\text { of Shar River }\end{array}$ & AN 7-16 & 50.1922 & 80.5418 & 5 \\
\hline "Balkhash" form & $\begin{array}{l}\text { East Kazakhstan Prov., Ust- } \\
\text { Kamenogorsk City }\end{array}$ & AN-17 & 49.9939 & 82.5219 & 1 \\
\hline P. cf. bedriagae & $\begin{array}{l}\text { East Kazakhstan Prov., } \\
\text { Ust-Kamenogorsk vicinity, Irtysh River }\end{array}$ & AN-18 & 50.0022 & 82.5036 & 1 \\
\hline P. cf. bedriagae & Pavlodar Prov., Pavlodar city & AN-19 & 52.2213 & 76.5226 & 1 \\
\hline $\begin{array}{l}\text { "Balkhash" + } \\
\text { P. cf. bedriagae }\end{array}$ & $\begin{array}{l}\text { Karaganda Prov., Karaganda fish } \\
\text { hatchery, near Solonchiki Village }\end{array}$ & AK 4-6 & 50.0653 & 73.2697 & 3 \\
\hline $\begin{array}{l}\text { "Balkhash" + } \\
\text { P. cf. bedriagae }\end{array}$ & $\begin{array}{l}\text { Karaganda Prov., Irtysh-Karaganda } \\
\text { Channel Tuzdy eldress, } 29^{\text {th }} \text { sector }\end{array}$ & AK 7-9 & 50.1504 & 73.3654 & 2 \\
\hline "Balkhash" form & Almaty City, Baum Grove & IA $46-47$ & 43.3093 & 76.9490 & 2 \\
\hline P. cf. bedriagae & East Kazakhstan Prov., Uba River Basin & A-R-35 & 50.6085 & 81.8730 & 1 \\
\hline "Balkhash" form & $\begin{array}{l}\text { South Kazakhstan Prov., western coast } \\
\text { of Balkhash Lake, Minaral }\end{array}$ & A-R-20 & 45.4350 & 76.6633 & 1 \\
\hline "Balkhash" form & $\begin{array}{l}\text { South Kazakhstan Prov., } \\
\text { Kishtobe Village vicinity, } \\
\text { Karatal River, right bank }\end{array}$ & A-R-29-32 & 45.3533 & 77.9166 & 4 \\
\hline "Balkhash" form & $\begin{array}{l}\text { Kyrgyzstan, northern coast } \\
\text { of Issyk-Kul Lake, } 22 \mathrm{~km} \text { west } \\
\text { of Grigoryevka Village }\end{array}$ & A-R-39 & 42.6451 & 77.2099 & 1 \\
\hline
\end{tabular}

